\title{
List of secondary legislation
}

.eu Domain Name Regulation: Regulation (EC) 733/2002 of the European Parliament and of the Council of 22 April 2002 on the implementation of the.eu Top Level Domain [2002] OJ L113/1, 30 April 2002

Alternative Dispute Resolution Directive: Directive 2013/11/ EU of the European Parliament and of the Council of 21 May 2013 on alternative dispute resolution for consumer disputes and amending Regulation (EC) 2006/2004 and Directive 2009/22/EC [2013] OJ L165/63, 18 June 2013

122, 291

Attacks Against Information Systems Directive: Directive 2013/40/ EU of the European Parliament and of the Council of 12 August 2013 on attacks against information systems [2013] OJ L218/8, 14 August 2013 375-80

Audiovisual Media Services Directive: Directive 2010/13/ EU of the European Parliament and of the Council of 10 March 2010 on the coordination of certain provisions laid down by law, regulation or administrative action in Member States concerning the provision of audiovisual media services (codified version) [2010] OJ L95/1, 15 April 2010. Amended by Directive (EU) 2018/1808, OJ L303/69, 28 November 2018
Brussels I Regulation (Recast): Regulation (EU) 1215/2012 of 12 December 2012 on jurisdiction and the recognition and enforcement of judgments in civil and commercial matters [2012] OJ L351/1, 20 December 2012 90-108, 284-9

Child Pornography Directive: Directive 2011/92/EU of the European Parliament and of the Council of 13 December 2011 on combating the sexual abuse and sexual exploitation of children and child pornography, and replacing Council Framework Decision 2004/68/ JHA [2011] OJ L26/1, 17 December 2011 132, 383-5

Collective Management of Copyright Directive: Directive 2014/26/EU of the European Parliament and of the Council of 26 February 2014 on collective management of copyright and related rights and multi-territorial licensing of rights in musical works for online use in the internal market [2014] OJ L84/72, 20 March 2014 248-9

Combating Fraud and Counterfeiting Directive: Directive (EU) 2019/713 of the European Parliament and of the Council of 17 April 2019 on combating fraud and counterfeiting of non-cash means of payment and replacing Council Framework Decision 2001/413/JHA, OJ L123/18, 10 May 2019 360-61 
Conditional Access Directive: Directive 98/84/EC of the European Parliament and of the Council of 20 November 1998 on the legal protection of services based on, or consisting of, conditional access [1998] OJ L320/54, 28 November 1998

Connected Continent Regulation: Regulation (EU) 2015/2120 of the European Parliament and of the Council of 25 November 2015 laying down measures concerning open Internet access and amending Directive 2002/22/EC on universal service and users' rights relating to electronic communications networks and services and Regulation (EU) 531/2012 on roaming on public mobile communications networks within the Union [2015] OJ L310/1, 26 November 2015

Consumer Injunctions Directive: Directive 2009/22/EC of the European Parliament and of the Council of 23 April 2009 on injunctions for the protection of consumers' interests (codified version) [2009] OJ L110/30, 1 May 2009

Consumer Rights Directive:

Directive 2011/83/EC of 25

October 2011 of the European Parliament and of the Council on consumer rights, amending Council Directive 93/13/EEC and Directive 1999/44/EC of the European Parliament and of the Council and repealing Council Directive 85/577/EEC and Directive 97/7/EC of the European Parliament and of the Council [2011] OJ L304/64, 22 November 2011 69, 258-63
Content Portability Regulation: Regulation (EU) 2017/1128 of the European Parliament and of the Council of 14 June 2017 on cross-border portability of online content services in the internal market, OJ L168/1, 30 June 2017 250-51

Copyright Directive (InfoSoc Directive): Directive 2001/29/ EC of the European Parliament and of the Council of 22 May 2001 on the harmonization of certain aspects of copyright and related rights in the information society [2001] OJ L167/10, 22 June 2001

Copyright in the DSM Directive: Directive (EU) 2019/790 of the European Parliament and of the Council of 17 April 2019 on copyright and related rights in the Digital Single Market and amending Directives 96/9/EC and 2001/29/EC, OJ L130/92, 17 May $2019 \quad$ 214, 223-31

Copyright Term Directive: Directive 2011/77/EU of the European Parliament and of the Council of 27 September 2011 amending Directive 2006/116/ $\mathrm{EC}$ on the term of protection of copyright and certain related rights [2011] OJ L265/1, 11 October 2011

Cybersecurity Directive (Also known as 'NIS Directive'): Directive 2016/1148/EU of the European Parliament and of the Council concerning measures for a high common level of security of Network and Information Systems across the Union [2016] OJ C218/1, 16 June 2016 $275,380-81$ 
Data Protection Directive: Directive 95/46/EC of the European Parliament and the Council of 24 October 1995 on the protection of individuals with regard to the processing of personal data and on the free movement of such data [1995] OJ L281/31, 23 November 1995

Data Retention Directive (no longer valid): Directive 2006/24/ EC of 15 March 2006 of the European Parliament and of the Council on the retention of data generated or processed in communication with the provision of publicly available electronic communications services or of public communication networks and amending Directive 2002/58/EC [2006] OJ L105/54, 13 April 2006 19, 298-9, 328-31, 373

Database Directive: Directive 96/9/ EC of the European Parliament and of the Council of 11 March 1996 on the legal protection of databases [1996] OJ L77/20, 27 March 1996 193, 195, 241-2

Design Regulation: Council Regulation (EC) 6/2002 of 12 December 2001 on Community Designs [2001] OJ L3/1, 12 December 2001

Digital Content Directive: Directive $2019 / 770$ on certain aspects concerning contracts for the supply of digital content and digital services, OJ L136/1, 22 May 2019
Distance Marketing of Consumer Financial Services Directive: Directive 2002/65/EC of the European Parliament and of the Council of 23 September 2002 concerning the distance marketing of consumer financial services, amending Directives 97/7/EC and 98/27/EC [2002] OJ L271/16, 9 October 2002

268, 271, 277

Distance Selling Directive: Directive 97/7/EC of the European Parliament and of the Council of 20 May 1997 on the protection of consumers in respect of distance contracts [1997] OJ L144/19, 4 June 1997

Doorstep Selling Directive: Council Directive 85/577/EEC of 20 December to protect the consumer in respect of contracts negotiated away from business premises [1985] OJ L372/31, 31 December 1985

E-Identification and Trust Regulation (eIDAS Regulation): Regulation (EU) 910/2014 of the European Parliament and of the Council of 23 July 2014 on electronic identification and trust services for electronic transactions in the internal market and repealing Directive 1999/93/EC [2014] OJ L257/73, 28 August 2014

Electronic Commerce Directive: Directive 2000/31/EC of the European Parliament and of the Council of 8 June 2000 on certain legal aspects of information society services, in particular electronic commerce, in the internal market [2000] OJ L178/1, 17 July $2000 \quad$ 46-68, $119,171,178$ 
E-Money Directive: Directive 2009/110/EC of the European Parliament and of the Council of 16 September 2009 on the taking up, pursuit and prudential supervision of the business of electronic money institutions, amending Directives 2005/60/ EC and 2006/48/EC and repealing Directive 2000/46/ EC [2009] OJ L267/7, 10 October 2009 $344,355-8$

ENISA Regulation: Regulation (EU) $2019 / 881$ of the European Parliament and of the Council of 17 April 2019 on ENISA (the European Union Agency for Cybersecurity) and on information and communications technology cybersecurity certification and repealing Regulation (EU) No 526/2013 OJ L 151/15, 7 June 2019

E-Privacy Directive (Directive on Privacy and Electronic Communications): Directive 2002/58/EC of 12 July 2002 of the European Parliament and of the Council concerning the processing of personal data and the protection of privacy in the electronic communications sector [2002] OJ L201/37, 31 July 2002, amended by Directive 2009/136/EC [2009] OJ L337/11, 18 November 2009 31, 297, 332-41

E-Signatures Directive: Directive 1999/93/EC of the European Parliament and of the Council of 13 December 1999 on a Community framework for electronic signatures [2000] OJ L13/12, 19 January 2000
European Electronic

Communications Code (EECC):

Directive (EU) 2018/1972 of

the European Parliament and of the Council of 11 December 2018 establishing the European Electronic Communications Code (Recast) [2018] OJ L 321/36, 17 December 2018 $35,38-40$

First Amending Directive (Telecoms): Directive 2009/136/EC of 25 November 2009 amending Directive 2002/22/EC on universal service and users' rights relating to electronic communications networks and services, Directive 2002/58/EC concerning the processing of personal data and the protection of privacy in the electronic communications sector and Regulation (EC) 2006/2004 on cooperation between national authorities responsible for the enforcement of consumer protection laws [2009] OJ L337/11, 18 December 200938

Framework Directive: Directive 2002/21/EC of 7 March 2002 on a common regulatory framework for electronic communications networks and services [2002] OJ L108/33, 24 April 2002 41, 328, 331

General Data Protection Regulation (GDPR): Regulation (EU) 679/2016 of the European Parliament and of the Council of 27 April 2016 on the protection of natural persons with regard to the processing of personal data and on the free movement of such data, and repealing Directive 95/46/EC [2016] OJ L119/1, 4 May 2016 
Geo-blocking Regulation: Regulation (EU) 2018/302 of the European Parliament and of the Council of 28 February 2018 on addressing unjustified geo-blocking and other forms of discrimination based on customers' nationality, place of residence or place of establishment within the internal market and amending, OJ L 60 I/1, 2 March 2018

80, 266-7

Human Trafficking Directive:

Directive 2011/36/EU of the European Parliament and of the Council of 5 April 2011 on preventing and combating trafficking in human beings and protecting its victims, and replacing Council Framework Decision 2002/629/JHA [2011] OJ L101/1, 15 April 2011

Intellectual Property Rights

Enforcement Directive (IPRE Directive): Directive 2004/48/ EC of the European Parliament and of the Council of 29 April 2004 on the enforcement of intellectual property rights [2004] OJ L195/16, 2 June 2004

149, 182, 232-9

Mediation Directive: Directive 2008/52 of the European Parliament and of the Council of 21 May 2008 on certain aspects of mediation in civil and commercial matters [2008] OJ L136/3, 24 May 2008 122, 291

Misleading Advertising Directive: Directive 2006/114 of the European Parliament and of the Council of 12 December 2006 on misleading and comparative advertising [2006] OJ L376/21, 27 December 2006
'Omnibus' Directive: Directive (EU) 2019/2161 of the European Parliament and of the Council of 27 November 2019 amending Council Directive 93/13/ EEC and Directives 98/6/EC, 2005/29/EC and 2011/83/EU of the European Parliament and of the Council as regards the better enforcement and modernisation of Union consumer protection rules, OJ L328/7, 18 December 2019

267-71

Online Dispute Resolution Regulation (ODR Regulation): Regulation (EU) 524/2013 of the European Parliament and of the Council of 21 May 2013 on online dispute resolution for consumer disputes and amending Regulation (EC) 2006/2004 and Directive 2009/22/EC [2013] OJ L165/1, 18 June 2013

Orphan Works Directive: Directive 2012/28/EU of the European Parliament and of the Council of 25 October 2012 on certain permitted uses of orphan works [2012] OJ L299/5, 27 October 2012

Payment Services Directive (2):

Directive 2015/2366/EU of the

European Parliament and of the Council of 25 November 2015 on payment services in the internal market, amending Directives 2002/65/EC, 2009/110/EC and 2013/36/ $\mathrm{EU}$ and Regulation (EU) $1093 / 2010$, and repealing Directive 2007/64/EC [2015] OJ L337/35, 23 December 2015 $273,358-60$ 
Police and Criminal Justice Authorities Directive: Directive 2016/680/EU of the European Parliament and of the Council of 27 April 2016 on the protection of natural persons with regard to the processing of personal data by competent authorities for the purposes of the prevention, investigation, detection or prosecution of criminal offences or the execution of criminal penalties, and on the free movement of such data, and repealing Council Framework Decision 2008/977/JHA [2016] OJ L119/89, 4 May 2016

Rental and Lending Rights Directive (original version): Directive 92/100/EEC of 19 November 1992 on rental right and lending right and on certain rights related to copyright in the field of intellectual property [1992] OJ L346/61, 27 November 1992

Rental and Lending Rights Directive (codified): Directive 2006/115/ EC of the European Parliament and of the Council of 12 December 2006 on rental right and lending right and on certain rights related to copyright in the field of intellectual property (codified version) [2006] OJ L376/28, 27 December 2006

Rome I Regulation: Regulation (EC) 593/2008 of the European Parliament and of the Council of 17 June 2008 on the law applicable to contractual obligations [2008] OJ L177/6, 4 July 2008

90, 108-12, 289-90
Rome II Regulation: Regulation (EC) 864/2007 of the European Parliament and of the Council of 11 July 2007 on the law applicable to non-contractual obligations [2007] OJ L199/40, 31 July 2007 112-16

Sale of Goods Directive: Directive 2019/771 on certain aspects concerning contracts for the sale of goods, amending Regulation (EU) $2017 / 2394$ and Directive 2009/22/EC, and repealing Directive 1999/44/EC, 22 May 2019, OJ L136/28

Sales and Guarantees Directive: Directive 1999/44/EC of the European Parliament and of the Council of 25 May 1999 on certain aspects of the sale of consumer goods and associated guarantees [1999] OJ L171/12, 7 July 1999 $72-3,258$

Satellite and Cable Broadcasting Directive: Council Directive 93/83/EEC of 27 September 1993 on the coordination of certain rules concerning copyright and rights related to copyright applicable to satellite broadcasting and cable retransmission [1993] OJ L248/15, 6 October 1993195

Second Amending Directive (Telecoms): Directive 2009/140/EC of 25 November 2009 amending Directive 2002/21/EC on a common regulatory framework for electronic communications networks and services, Directive 2002/19/EC on access to, and interconnection of, electronic communications networks and associated facilities, and Directive 2002/20/EC on the authorization of electronic communications networks and services [2009] OJ L337/37, 18 December 2009 38,41 
Services Directive: Directive 2006/123/EC of the European Parliament and of the Council of 12 December 2006 on services in the internal market [2006] OJ L376/36, 27

December $2006 \quad 51, \mathbf{8 0}-\mathbf{8 1}$, 242-3, 260, 266

Software Directive (original version): Council Directive 91/250/EEC of 14 May 1991 on the legal protection of computer programs [1991] OJ L122/42, 17 May $1991 \quad \mathbf{1 9 3}, \mathbf{1 9 5}, 232$

Software Directive (codified): Directive 2009/24/EC of the European Parliament and of the Council of 23 April 2009 on the legal protection of computer programs (codified version) [2009] OJ L111/16, 5 May 2009

$218,232,242-4$

Technical Standards Directive:

Directive 98/34/EC of the European Parliament and of the Council of 22 June 1998 laying down a procedure for the provision of information in the field of technical standards and regulations and on rules on information society services [1998] OJ L204/37, 21 July 1998

Telecommunications Privacy

Directive (ISDN Directive):

Directive 97/66/EC of the European Parliament and of the Council of 15 December 1997 concerning the processing of personal data and the protection of privacy in the telecommunications sector [1997] OJ L24/1, 15 December 1997 282, 338
Terrorism Directive: Directive (EU) 2017/541 of the European Parliament and of the Council of 15 March 2017 on combating terrorism and replacing Council Framework Decision 2002/475/ JHA and amending Council Decision 2005/671/JHA, OJ L88/6, 31 March 2017 136, 386-8

Trademark Directive: Directive 2015/2436/EU of the European Parliament and of the Council of 16 December 2015 to approximate the laws of the Member States relating to trademarks [2015] OJ L336/1, 23 December 2015

Trademark Regulation: Regulation (EU) $2424 / 2015$ of the European Parliament and of the Council of 16 December 2015 amending Council Regulation (EC) 207/2009 on the Community trademark and Commission Regulation (EC) 2868/95 implementing Council Regulation (EC) 40/94 on the Community trademark, and repealing Commission Regulation (EC) $2869 / 95$ on the fees payable to the Office for Harmonization in the Internal Market (Trade Marks and Designs) [2015] OJ L341/21, 24 December 2015 99, 244

Trade Secrets Directive: Directive 2016/943/EU of the European Parliament and of the Council of 8 June 2016 on the protection of undisclosed know-how and business information (trade secrets) against their unlawful acquisition, use and disclosure [2016] OJ L157/1, 15 June 2016 
Transparency Regulation:

Regulation (EU) 2019/1150

of the European Parliament and of the Council of 20 June 2019 on promoting fairness and transparency for business users of online intermediation services, OJ L 186/57, 11 July 2019

Unfair Commercial Practices

Directive (UCP Directive):

Directive 2005/29/EC of the European Parliament and of the Council of 11 May 2005 concerning unfair business-to-consumer commercial practices in the internal market and amending Council Directive 84/450/EEC, Directive 97/7/EC, Directive 98/27/EC and Directive 2002/65/EC of the European Parliament and of the Council and Regulation (EC) 2006/2004 of the European Parliament and of the Council [2005] OJ L149/22, 11 June $2005 \quad 51,276$
Unfair Terms in Consumer Contracts Directive: Directive 93/13/EEC of 5 April 1993 on unfair terms in consumer contracts [1993] OJ L95/29, 21 April 1993 106,

\section{3-5}

Universal Service Directive:

Directive 2002/22/EC of the European Parliament and of the Council of 7 March 2002 on universal service and users' rights relating to electronic communications networks and services [2002] OJ L108/51, 24 April 2002 
Andrej Savin - 9781789908572 Downloaded from PubFactory at $04 / 26 / 2023$ ०9:47:32AM via free access 